\title{
NEED ANALYSIS FOR IDENTIFYING ESP MATERIALS FOR MEDICAL RECORD STUDENTS IN APIKES CITRA MEDIKA SURAKARTA
}

\author{
Beta Setiawati \\ Apikes Citra Medika Surakarta \\ setiawatibeta@gmail.com
}

\begin{abstract}
Identifying teaching material is the process of selecting, adapting and evaluating of teaching based on specific necessities of the students. Need Analysis is really needed to identify teaching materials for English for Specific Purpose. The researchobjective is toidentify the ESP materials for teaching $3^{\text {rd }}$ semester medical record students at Academy of Medical Record and Health information Citra Medika (APIKES CITRA MEDIKA) Surakarta. The work used qualitative and quantitative methods. The outcomesof this study showed the real necessities of students in learning English to prepare their future at the field of medical record and health information. Findings of the need analysis demonstrate that all four of the language skills were necessary for their academic studies and their target career. There are certain topics related to English for medical record such as medical record staff' duties, ethical and legal issues in medical record, Hospital statistics, Medical record filling system, Health information system, and so on. Accordingly, this study proposes new ESP materials based on the stakeholders'needs.It is suggested that textbook or handout of English for Medical Record will be made based on the Need Analysis by ESP designers and ESP lecturers involve actively recognizing the progressive needs of medical record students.
\end{abstract}

Keywords: Identifying, ESP Materials, Need Analysis, Medical Record Students

\begin{abstract}
Abstrak
Mengidentifikasi materi perkuliahan adalah proses menyeleksi, menyesuaikan, dan mengevaluasi materi perkuliahan berdasarkan kebutuhan khusus mahasiswa. Analisis kebutuhan sangat dibutuhkan untuk mengidentifikasi materi perkuliahan ESP. Tujuan penelitian ini adalah untuk mengidentifikasi materi ESP untuk mengajar mahasiswa jurusan D3 perekam medis dan informatika kesehatan di APIKES CITRA MEDIKA Surakarta. Peneliti menggunakan metode kualitatif dan kuantitatif dalam pengumpulan data. Hasil penelitian menunjukkan keperluan yang spesifik mahasiswa perekam medis dan informatika kesehatan semester 3 terhadap pembelajaran bahasa Inggris.Dengan menggunakan analisis kebutuhan, peneliti menunjukkan bahwa semua ketrampilan bahasa sangat penting dalam kegiatan akademis dan profesi yang akan mereka tekuni setelah lulus. Beberapa topik yang sesuai dengan kebutuhan mahasiswa rekam medis adalah tentang tugas-tugas staf perekam medis, isu- isu yang berkaitan dengan moral dan hukum dalam profesi rekam medis, statistik rumah sakit, sistem pengisian rekam medis, sistem informasi kesehatan, dan yang lainnya. Penelitian ini juga mengusulkan materi ESP baru untuk menyesuaikan kualitas lulusan dengan pihak rumahs akit atau klinik yang akan mempekerjakan mere-
\end{abstract}


ka. Buku pegangan yang digunakan untuk mengajar bahasa Inggris di jurusan perekam medis dan informasi kesehatan sebaiknya disusun berdasarkan analisis kebutuhan dan pengajar ESP sangat diharapkan berperan aktif dalam mengidentifikasi kebutuhan-kebutuhan bahasa Inggris dalam dunia rekam medis yang selalu berkembang.

Kata Kunci: Identifikasi, Materi ESP, Analisis Kebutuhan, Mahasiswa Perekam Medis

\section{Introduction}

The number of studentsstudying to be medical record staff in Indonesia has increasedover the years. In relation to globalization era, students graduated from medical record department must have communicative competence and the specific English language competence to carry out responsibilities of being medical record staff. Since there are developing numbers of International standardized hospitals so lecturers must also be challenged to develop the quality of students in that field. One of the stepsto improve the students' quality is to design ESP syllabus based on need analysis.

APIKES Citra Medika Surakarta is one of institution which hold medical record department. Its goal is to prepare human resources especially in medical record professional staff. It accomplishes this goal through some programs. One of them is by giving English material at the first, second, and third semester. At the third semester, the English material tends to focus in English for Specific Purposes (ESP). Through this program, APIKES expects English language teaching meets the specific academic and professional communication needs of learners who seek to improve their language skills.ESP reflects learners' specific purpose in learning the target language, being a response to learners' needs and the acquisition of language relevant to communication outside the classroom, especially in their studies and future careers. On the other hand, lecturers' preparation of teaching ESP has not done systematically based on need analysis. They generally make teaching outlines about what they are going to teach without using syllabus, so sometimes the material is not suitable with the students' needs.
A specific needs analysis exercise was not conducted in preparation for the designing of a syllabus and no information is provided regarding objectives, teaching materials, and assessment. As the result, the language output of ESP teaching is not as effective as the institution's expectation. The unsatisfactory results of teaching ESP for medical record students may primarily be due to inappropriate way the syllabus has been designed and the way teaching materials have been selected. This paper will then discuss about the needs of English for medical record students. After analyzing those needs, the writer will design ESP syllabus for the third semester students of medical record based on need analysis.

\subsection{English for Specific Purposes (ESP)}

ESP deals with preparing the learners to become able to use English in academic, professional or workplace settings. As it is about specific students, therefore, it must be tailored to the needs of these students (Akbari, 2014). It can be inferred that it is a way of teaching or learning English for specialized subjects with some specific vocational and educational purposes in mind. In ESP syllabus, the teaching content is geared to the special language 'repertoire' pertaining to the specialized aims that are required of the learners. ESP is a relatively new discipline within Applied Linguistics that offers a new learner-centered approach to English language teaching whose methodology is based on the specific needs of the learner. Yalden in Saragih (2014) argues that setting up a new course implies a skillful blending of what is already known about language teaching and learning with the new elements 
that a group of learners bring to the classroom, for example their own needs, wants, attitudes, knowledge of the world. Therefore, designing materials should be adapted with learners' need of studying English for certain need. ThenESP is used as a specific approach to language teaching that requires all decisions from content to method and will be based on the learner's purpose for learning.

Akbari (2014) emphasized that analyzing the specific needs of a particular learner group serves as the introduction to an ESP course design, because it determines the 'what' and 'how' of an ESP course. Most of the researchers agreed that ESP is intended to provide for learners' specific needs in particular disciplines. It employs a specific different methodology from General English as it focuses on some activities in a particular area of study or discipline with its special discourse, semantics, syntax, etc. In the other side, Saragih (2014) believed that analyzing the specific needs of particular group of learners serves as an important starting point in ESP course design for it determines the essence and the underlying reasons of an ESP course. It will help select and prioritize students' need. Besides, the purpose of ESP course is to enable learners to function adequately in a target situation in which learners will use the language they are learning. Design of an ESP course needs to be prepared well to have goal-oriented materials while keeping in mind the learners' specific needs.

As Bracaj (2014) explained that students learn English for a specific purpose, represented by studying subject matter, to gain and develop appropriate knowledge and skills through English. Students study ESP not only they are interested in English language but because they have to perform a task in English. Their command of the English language must be such that they can reach a satisfactory level in their specialist subject studies. In other words, students who have studied English for Specific Purposesduring their universities years, would be easy for them to adapt to their work conditions and would be easily employed in their fields. Beshaj (2015) added the necessity of ESP method related to international exchanges and interactions that the recent conditions need to have people know not just general English but to have extensive English vocabulary on various specific scientific such as judicial, social, medical fields, and so on. Therefore it is obvious that knowing English and using English for specific purposes is a challenge. People would be much appreciated if they have good command not only the general foreign language but alsohave a specific field.

It is also clear that almost all ESP definitions are around two areas. The first is about the ESP participants or learners' needs, such as English for Medical students. The second is around the language used in real-life context (e.g. English in a hospital, hotel, or office). The two features of ESP are closely connected to every aspect of ESP teaching in order for a practical purpose to be achieved. What seems difficult in describing ESP is the careful effort in deciding the kind of discourse, such as vocabulary terminology or register that is to be taught and to reflect accurately the purpose in a specific context the learners need (e.g. writing the report of medical record data, patient-medical record staff talk, and noting the doctor diagnosis.Discourse diversity can be so overwhelming and confusing to ESP course designers as the learners' needs analysis can produce a large numbers of needs, purposes, and discourse.

\subsection{ESP and Need Analysis}

"Needs Analysis (NA) is avital stage in designing ESP materials" (Belcher, 2006, p.135). It represents a basis in identifying the course objective, and learners' communicative and linguistic needs. Researchers define NA differently, but many of them agree that NA reflects necessities, wants and needs of learners in their subject area. In addition, most of researchers regarded NA as the process of deciding the learn- 
ers' English language skill, finding related linguistic, genre, and discourse information, determining what is expected out of the course, and finally establishing how the course will be administered and run.The essential feature of ESP design is to effectively analyze learners' communicative needs to ensure successful learning and teaching experience. ESP course developers, therefore, should immense themselves in analyzing students' needs before designing their courses.

In terms of ESP's main characteristics, there is, nevertheless, common agreement among ESP researchers that the learners' needs in ESP is very important and it has been the driving force in any ESP course design since the emergence of ESP courses in the 1960s. Brown in Akbari (2014) illustrated need analysis as the systematic collection and analysis of all subjective and objective information necessary to define and validate defensible curriculum purposes that satisfy the language learning necessities of students within the context of particular institutions thatinfluence the learning and teaching situation. Mohammadi and Mousavi in Akbari (2014) also explained that in this definition, the idea of defensible curriculum deals with the accountability of the course meeting, the requirements of a particular group of students and their instructors or other stakeholders

However, ESP can be taught to beginners if careful attention is given to needs analysis and to an appropriate material design addressing the level of students. It can be inferred that the concept of 'needs' is so dominant in any ESP curriculum. Therefore the irrelevant materials are not to be included in the ESP syllabus. All researchers give strong emphasis on analyzing the learners' need in order to arrive at a proper ESP syllabus. Needs Analysis is then anessential stage as it tells syllabus developers about the specific language used by the learners in their own contexts. Course writers, therefore, can manage to develop real-life simulative materials.
In literature on health care professional settings, Hwang (2011) attempted to analyze and to identify that teaching materials and activities provided in class must be appropriate toprofessional and career-related syntax, vocabulary, and discourse that learners need in order to participate,particularly in spoken and written genres. Then, learning outcomes should be introduced in terms of performance assessment, and what a learner can master by the end of a course. To balance these roles, ESP teachers need to possess a great deal of flexibility and be interested in the disciplines or professional activities in which the students are involved. Moreover, teachers should be willing to be challenged and be armed with a sound knowledge of both theoretical and practical developments to empower them to make good decisions that lead to the successful contribution of ESP education for medical students.

\subsection{ESP Curriculum Development}

Materials development is both a field of study and a practical undertaking. It is basically the process of planning and implementing a certain curriculum. In the similar way, curriculum development isconsidered asa number of tasks and materials combined in one design. In other words, a language curriculum developmentdiscusses about what and how students and teachers interact in the learning and teaching process.

Concerningto ESP curriculum for medical students, Hwang (2011) found that students and faculty members were in agreement that the materials in the English course should be relevant to the medical field.Based on the responses of students and faculty, the best pattern of curriculum design for English courses was general English in the freshman year, followed by medical English in the second and third years. This finding is congruent with the previous finding that materials in an English course should be relevant to the medical field, and probably points out that medical students feel that medical English is very important. 
So, medical students need ESP curriculum.

ESP curriculum is a specific one and that there are certain steps that must be followed to develop ESP syllabuses such as analyzing learners' needs, planning authentic and reliable materials, finding relevant and appropriate discourse, deciding the language activities and task, editing the syllabus, and as a final pointconductingthe syllabus design in a class and evaluating the materials. General English curriculum usually contains English language needs, but ESP curriculum considers both of the general and specific English in reaching the goal, which is learners will be competent to use English in their specific field or profession. For example, an ESP syllabus in medical record needs to focus more on specific Latin and English terminology to understand ICD as the main source of students in this major. It should be consequently noted that ESP learners' needs is significantly determined by their major and thus influences the particular aspects of planning syllabus. Nunan and Carter (2008) argued that need analysis is to be carefully oriented toward learner-centered methodology.

As discussed above, ESP syllabus needs to be made as learner-centered syllabus which makes curriculum development goal-oriented and designed to the specific needs of learners. At this time, there is not any book or handout that contains material that is really needed by the students of medical record to support their professional career in the hospital in the future. To solve this problem, the writer wanted to design materials based on ESP Needs Analysis. This research has two main objectives: 1) to explore the needs of medical record students on English materials 2) to design ESP materials for medical record students based on Need Analysis. The Need Analysis of ESP adopted in this research is comparing between target situation analysis and present situational analysis, want analysis and lack analysis, learning need analysis and linguistic analysis to find a balance syllabus that is appropriate for the students.

\section{Method}

Participants of this study were fifty medical record students at the third semester in APIKES Citra Medika Surakarta (they were randomly chosen from 6 classes), 4English lecturers, and fourpersons who worked as medical record staff. This research used both qualitative and quantitative methods to investigateEnglish materials to focus in learner-centered based on need analysis for students of medical record in APIKES Citra Medika Surakarta. The data were collected from several sources such asmedical record students, English lecturers, hospital medical record staff, and ESP experts. It was intended to provide different perspectives, which supports researchers to analyze about something from a lot of points of view. The research used tests, questionnaire, and interview to get the data. The data collected based on need analysis and contribution from the experts were used to design the new materials of ESP for the third semester students of medical record in this institution.

The instruments used were questionnairesfocusing on personal information and English proficiency, students' strength and weaknesses in English proficiency, medical record students' interest on English language skills, the conditions that need English for medical record students, medical record staff topic for sharing with colleagues and patients, medical record students' favorites activities in learning English, and medical topics the medical record students want to learn. The writer completed the information ESP materials for medical record students by interviewing 4 English lecturers in Citra Medika and 4 medical record staff working at the hospital.The questionnaire data were analyzed quantitatively, and the interview data were analyzed qualitatively.

\section{Findings and Discussion}

\subsection{The Results from Questionnaire}

This section describes the results from questionnaire. Questionnaires are made based on personal information about Eng- 
lish proficiency and students' needs toward ESP class.

Table 1. Personal Information and English Proficiency

\begin{tabular}{llcc}
\hline \multicolumn{1}{c}{ Questions } & \multicolumn{1}{c}{ Options } & Frequency & Percentage \\
\hline How old are you? & $18-22$ & 43 & 86 \\
& $22-25$ & 5 & 10 \\
Do you study English previously? & More than 25 & 2 & 4 \\
& Yes & 50 & 100 \\
Do you try to improve your English & No & 0 & 0 \\
& Yes & 24 & 48 \\
How many hours do you practice English out of & No & 26 & 52 \\
your campus? & Not at all & 26 & 52 \\
& $1-2$ hours & 22 & 44 \\
\hline
\end{tabular}

As described in the table, the category of medical record students' age is classified into 3 groups and the dominant percentage of students' ages is on the group of 18-23, and most of them do not have any intention to improve their English ability.

Table 2. Students' Strength and Weaknesses in English proficiency

\begin{tabular}{lccc}
\hline \multicolumn{1}{c}{ Skills } & Weak $\%$ & Fair\% & Good\% \\
\hline Pronunciation & 43 & 3 & 4 \\
Grammar & 8 & 37 & 5 \\
Vocabulary & 40 & 7 & 3 \\
Writing & 12 & 36 & 2 \\
Listening & 36 & 10 & 4 \\
Speaking & 20 & 13 & 17 \\
Reading & 12 & 30 & 8 \\
\hline
\end{tabular}

The table shows the description of students' ability in English proficiency.The highest percentage of students' weakness is in the pronunciation skill. Whereas the highest percentage of the students' strength is called as "fair" is in Grammar skill.In "pronunciation"most students have high percentage weakness as well as the ability of "Vocabulary and Pronunciation" while they are mostly good in the ability of "Reading and Writing".

Table 3. The medical record students' interest on English language skills

\begin{tabular}{lcccc}
\hline \multicolumn{1}{c}{ Skills } & High interest & $\begin{array}{c}\text { Middle inter- } \\
\text { est }\end{array}$ & Low interest & No Interest \\
\hline Writing & $40 \%$ & $18 \%$ & $22 \%$ & $20 \%$ \\
Reading & $15 \%$ & $40 \%$ & $38 \%$ & $6 \%$ \\
Listening & $53 \%$ & $26 \%$ & $15 \%$ & $6 \%$ \\
Speaking & $67 \%$ & $23 \%$ & $8 \%$ & $2 \%$ \\
\hline
\end{tabular}

Table 3 indicates the interest percentage of students on each English language skills. Most of them are very attracted in learning ESP especially in speaking activities 
Table 4. The conditions that need English for medical record students.

\begin{tabular}{lcc}
\hline \multicolumn{1}{c}{ Situations } & Frequency & Percentage (\%) \\
\hline Explaining to the patients & 28 & 56 \\
Explaining drug interactions & 35 & 70 \\
Calling by phone & 35 & 70 \\
Giving information & 35 & 70 \\
Giving instructions & 30 & 60 \\
Checking understanding & 21 & 42 \\
Explaining laboratory tests & 26 & 56 \\
Administering medications & 18 & 36 \\
Coding & 40 & 80 \\
Writing medical records & 39 & 77 \\
Reading prescription charts & 14 & 28 \\
Reading patients' records & 38 & 76 \\
Requesting information by e-mail & 4 & 8 \\
Replying letter by e-mail & 3 & 6 \\
Presenting the result of study & 38 & 76 \\
Writing academic report or journal & 18 & 35 \\
\hline
\end{tabular}

The table describes the most commonly situation that request students of medical record use English. The highest percentage is coding then the lowest rank is replying letter by e-mail.

Table 5. Medical record staff topic for sharing with colleagues and patients.

\begin{tabular}{|c|c|c|}
\hline Topics & Frequency & Percentage $(\%)$ \\
\hline Family & 45 & 90 \\
\hline Lifestyle & 27 & 54 \\
\hline Food & 29 & 58 \\
\hline Fashion & 17 & 34 \\
\hline Natural features & 35 & 70 \\
\hline Job & 40 & 80 \\
\hline Culture & 34 & 68 \\
\hline Hobbies & 28 & 56 \\
\hline Others & 10 & 20 \\
\hline
\end{tabular}

In the table above, the most common topics shared by medical record staff with patients and colleagues are those related to
Family where as the topics which are less shared by medical record staff are the topics of Fashion and Others.

Table 6. The medical record students' Favorites Activities in Learning English

\begin{tabular}{lcc}
\hline \multicolumn{1}{c}{ Activities } & Frequency & Percentage (\%) \\
\hline Pair work & 25 & 50 \\
Whole class & 15 & 30 \\
Group work & 35 & 70
\end{tabular}




\begin{tabular}{lll} 
Out of class work & 8 & 16 \\
Individual & 5 & 10 \\
\hline
\end{tabular}

Table 6 describes that the most required activities by medical record students in learning ESP are group work activities.
Most of the students do not like individual activities in learning English.

Table 7. The English medical topics the medical record students want to learn

\begin{tabular}{lcc}
\hline \multicolumn{1}{c}{ Topics } & Frequency & Percentage (\%) \\
\hline Medical record staff' duties & 39 & 78 \\
ethicaland legal issues in medical record & 28 & 80 \\
Medicalrecord sciences & 43 & 86 \\
Hospital statistics & 36 & 72 \\
Medical treatment & 42 & 84 \\
Medical record administration & 15 & 30 \\
Medical record filling system & 45 & 90 \\
Indexes and classification system & 20 & 40 \\
Organization of healthcare service & 7 & 14 \\
Health information system & 16 & 32 \\
Authentication in medical record & 16 & 32 \\
\hline
\end{tabular}

Table 7 shows that the students really need to learn English especially about medical record filling system for their academic necessity.

\subsection{The Results from Interview}

\subsubsection{Medical Record Staff in The Hospi- tal}

The following outlines the results of interview with four professional medical record (MR) staff in Moewardi Hospital of Surakarta to get complete information about English materials that are needed to arrange in relation with medical record staff. According to thosefour MR staff, the majority of MR staff serve these things: (1) Gathers patient information by collecting demographic information from a variety of sources; interacting with registration areas and physicians' offices; retrieving information from automated printer. (2) Maintains master patient index by completing assigned portion of daily audit trail; corrects and communicates problems according to established procedures. (3) Initiates the medical record by creating and processing the patient care record folder (4)Maintains record availability by processing charts into the department; using chart mark-off procedures; facilitating chart location activities. (5) Retrieves medical records by following chart-out procedures; documenting reasons charts cannot be retrieved for statistical and follow-up purposes. (6) Delivers charts to assigned areas of the hospital by following established routing procedures. (7) Keeps health care providers informed by communicating availability or unavailability of the record (8) Maintains quality results by following hospital standards (9)Maintains continuity of work operations by documenting and communicating actions, irregularities, and continuing needs (10) Maintains patient confidence by keeping patient records information confidential (11) Serves and protects the hospital community by adhering to professional standards, hospital policies and procedures, federal, state, and local requirements (12) Enhances medical records and hospital reputation by accepting ownership for accomplishing new and different requests; exploring opportunities to add value to job accomplishments 
Those fourmedical record staff said that firstly they felt anxious when they had to interact with foreign patients. They liked talking with patients but they did not have enough confidence because they felt that they had complicated problem with vocabularies and pronunciation. They feltafraid of having misinterpretations related to their bad pronunciation. In fact there were many situations where the patients could not understand them. Patients' accent often caused misunderstanding. Other problems of the medical record staff were found when they communicated with patients. They were relating to lack of vocabulary, sentence construction, and making questions. As a result, the medical record staff had to ask for explanation and repetition for many times. Problems also occurred when medical recordstaff were required to give explanations for example appointments and time expressions. Another medical record staff said that they had to practice more with listening skills so that misunderstanding in communicationwith patients could be reduced.

\subsubsection{ESP Lecturers}

Four ESP lecturers of APIKES Citra Medika Surakarta were interviewed to have clear information about their experiences on teaching English for medical record. Most of lecturers said that they did not have curriculum for teaching ESP for medical record. So, they should find out the sources from available books whichgenerally contain general and academic English. In order to adapt with the objectives of the ESP instructions, sometimes they searched material from medical sites from Internet. All the lecturersdid not write any lesson plan and handout of ESP for medical record. There was not any coordination among ESP lecturers to design syllabus and a certain course book. As a consequence, different lecturers have different ESP materials for their students and the institution seemed to have no standard of ESP competency. As a result, the materials for evaluation did not measure the real competency of the ESP students. The four ESP lecturers agree that there must be a special ESP training for them to improve their skills in teaching ESP for medical record.

Regarding to the topics they chose to teach, a lecturer said that they used 75 percent of the allocated time to teach general English language skills; listening, speaking, reading and writing on general topics. Then another three lecturers said that they involve 60percent of medical English for the students. The topics they taught were English language skills relating to diseases, nursing care, medicine, parts of body and medical treatments. All of the lecturers planned the English materials to improve students' ability in academic studies such as presenting medical cases, coding, understanding medical terms, and in target career for instance doing job interview, writing job application and $\mathrm{CV}$, understanding medical terms related to their jobs.

\subsection{Identifying ESP Materials for Med- ical Record Students}

Thedetail information of questionnaire and interview shows that English has a vital role to play in medical record community. This vital role requires those who want to be medical record professionals to study in order to acquire at least a goodknowledge of both written and spoken English. This results in a crucial demand to learn and teach English in the medical record field, not only for general purposes but also, more significantly, for specific ones. The materials we are trying to identify are destined to third semester students of Medical Record and Health Information. It focuses on the improvement of the learners' ability to use English orally and in writing, and the specialized vocabulary to prepare them to be able to successfully deal with professional requirements when they graduate

Most of the students in this academy do not have any intention to improve their English ability because they have been very busy to study many medical record subjects. 
At the third semester, they also take much time to practice their skill at the hospitals as the scheduled activity of their academy. Consequently the materials should be simple, practical, and interesting. The materials should also be able to stimulate their interests and directly influence their academic skills.

It is shown in table 2 that medical record students are mostly good in the ability of reading and writing. Reading materials can be designed by providing reading texts about medical terminology. Those texts help the students to break some medical terms into suffixes and prefixes. Automatically they also help them in their pronunciation. Therefore, when they are reading a text and come across with unfamiliar words, they can use their knowledge of prefixes and suffixes to guess the meaning of new words. Supplementary reading textbook that contains of Medical Terminology could help the students in their reading and comprehension ability. Some of related topics for reading are illness, symptoms, parts of the body, patient information in the form of demographic information from a variety of sources, explanation about drug interaction, hospital issues related to the medical record, laboratory test results, medical record filling system, and scientific journal of medical record.

Regarding the speaking skills, results of the data revealed that the highest interest percentage of students is on speaking skill. This good opportunity enables lecturersto provide certain situation to stimulate them to practice speaking in pairs or in-group. Those related situations are around explaining patients' medical record, calling doctors or medical staff, giving instruction to the patients, explaining laboratory test, and job interview. The practice can be done individually for presenting academic report in front of the class.Answering verbal cues is commonly used in classroom teacher-student interactions because it is a good technique to raise students' motivation and to ensure their involvement into the subject. Interac- tive conversations may consist in answering teachers' questions about the material after a silent reading.

Writing takes a big portion of classroom tasks, and again the participating lecturers should present activities about punctuation, parts of speech, verb-subject agreement, filling in the blanks, describing, tenses, synonymy, homonymy, and many others. The lecturers' choices are based on learners' weaknesses at a given aspect and the appropriateness of the task to the specialized material such as filling in the medical drafts, replying email, writing medical report, summarizing medical texts, and writing journal or medical research.

Listening skill is horrible for many students. Students rarely listen to native speaker talking about medical cases or audio related to medical terms. They typically cause the difficulty of mastering this skill. Dealing with this problem, the lecturers can play video about doctor's talk, patients' complaint, medical speech, and some other similar materials so that students can be easier to understand the oral presentation by looking at the visual appearance. It will be more enjoyable for the students to absorb some difficult talk by the visual aids.

\section{Conclusion}

The data resulted from the students' questionnaire and lecturers' interview have explainedsome issues which need to be considered as they offer significant suggestions for introducing curricular change. First of all, the findings of the study revealed the need for setting up a language course with a certain focus on English for Specific Purposes and on the target discipline, English for Medical Record and Health Information. In addition, there is a finding exposing the present ESP learning has not fulfilled the students' necessity in their future jobs. By knowing this fact, the lecturers can cooperate to identify ESP materials to improve the students' quality especially in English lesson. 
There were several important aspects to identify ESP materials for certain fields. They include need analysis, ESP curriculum, situational analysis and interviews that helped to specify the course. Among the important topics related to the medical record staff are maintaining patient files, retrieving files for scheduled appointments, filing study patient charts, filing all patient data upon receipt of information, initiating records for new patients, creating computer index, preparing file labels, and so on. Doing the research based on need analysis can reveal those topics. Besides, it can specify and focus the new design of ESP materials.
As the medical profession system changes from time to time, the materials should also be evaluated periodically to adapt the students' and profession needs.

In conclusion, it should be emphasized that, regardless of the amount of appropriate qualityreadily available textbooks or handouts, ESP teachers can always select for designingspecific materials, which can be used in combination with available textbooks or on their own. The materials must best fit the students' needs and specific subject areas to enhance their motivation for learning.

\section{References}

Akbari, Zahra. (2014). Academic English Needs of Iranian Paramedical Students and Practitioners: An ESP Context. International Journal of Language and Applied Linguistics World. 5 (2) pp. 274-286.

Allwright, D. and Bailey, K. M. (1994). Focus on the Language Classroom. Cambridge, Cambridge University Press.

Belcher, D. (2006).English for specific purposes: teaching to perceived needs and imagined futures in worlds of work, study, and everyday life. TESOL Quarterly. 40(1) pp. 133156.

Beshaj, Lediana. (2015). The Growing Importance of English for Specific Purposes (ESP) in Albanian Higher Education.International Journal on Studies in English Language and Literature. 3 (6) pp. 10-13.

Bracaj, Morena. (2014). Teaching English for Specific Purposes and Teacher Training.European Scientific Journal. 10 (2) pp. 40-49.

Flowerdew, J., \& Peacock, M. (2001). The EAP curriculum: Issues, methods, and challenges. In J. Flowerdew, \& M. Peacock (Ed.), Research perspectives on English for Academic purposes. (pp. 177-194). Cambridge: Cambridge University Press.

Hwang, Yanling. (2011). Pedagogical Implications on Medical Students'Linguistic Needs. Journal of English Language Teaching. 4 (4) pp. 138-145.

Litwack, D. M. (1979). Procedure: The key to developing an ESP curriculum. TESOL Quarterly. 13, 383-391.

Lowe I (2009).www.scientificlanguage.com/esp/needsanalysis.pdf Needs Analysis.

Miyake, M., \&Tremarco, J. (2005).Needs Analysis for Nursing Students Utilizing Questionnaires and Interviews.Kawasaki Journal of Medical Welfare, 1, 23-34.

Nunan, D. (2008). The Learner-Centred Curriculum. Cambridge: Cambridge Applied Linguistics.http://dx.doi.org/10.1017/CBO9781139524506

Saragih, Erikson. (2014). Designing ESP Materials for Nursing Students Based On Needs 
Analysis.International Journal of Linguistics. 6 (4) pp. 59-70.

Strevens, P. (1988). ESP after twenty years: A re-appraisal. In M. Tickoo (Ed.), ESP: State of the Art (pp. 1-13). Singapore: Seamco Regional Centre. 